\title{
Was Charles Guiteau Insane?
}

\author{
Mike McIntyre
}

The following manuscript was prepared for HIST 4680 The U.S. in the Era of Urbanization, under the supervision of Professor McShane Galley, Department of History, College of Arts.

A fter fatally shooting United States President James Abram Garfield on July 2, 1881, Charles Julius Guiteau was apprehended and tried for murder the following year in what became one of the most celebrated and controversial cases of the nineteenth century.

Guiteau was found guilty of pre-meditated murder in the first degree on January 25, 1882 and was subsequently sentenced to hang that summer as a consequence of his actions. ${ }^{1}$ While there can be no doubt that Guiteau was indeed the man who pulled the trigger of the pistol that fired two bullets into President Garfield, his motives and questionable mental competency to stand trial is something that is still argued to this day. As with many disciplines at the time, the field of psychiatry was still evolving and the concept of being mentally unfit to stand trial for ones actions was a relatively new and seldom-used defense. Through a close investigation of the beliefs and actions of Charles Guiteau leading up to his crime, it becomes apparent that he was indeed insane.

When examining Guiteau's difficult childhood and early introduction to religious fanaticism it becomes clear where his delusionary nature was fostered. Mental illness was something that was rampant in his family history. Guiteau's actions before and during the trial itself also reveal a man who was not mentally balanced. This paper will explain why, despite all of these obvious signs of mental illness, Charles Guiteau was hanged on June 30, 1882. American society's views on insanity had not developed sufficiently enough to believe such a plea in a case of such enormous magnitude.

The childhood of Charles Guiteau was anything but typical. His father, a religious zealot, physically abused him during his youth for reasons as trivial as for mispronouncing certain words. Mental illness was common in his immediate family as both his older sister and his mother exhibited signs of the disease. ${ }^{2}$ His sister, Frances Guiteau, was declared insane by her husband in 1882 and suffered seizures quite often. Guiteau's mother, Jane Howe Guiteau, was confined to her bed during the time Charles was born. She suffered from what doctors called, "brain fever" and her condition worsened with post-partum depression after his birth. She died at the age of forty three when Charles was merely a seven year old boy. When Charles' father remarried five years later, it sent his son into a fit of rage that did not help his mental development. ${ }^{3}$ Outside of the immediate family, several of Guiteau's uncles and cousins were held in institutions for the insane.

Luther Guiteau, Charles' father, was a man who held extreme religious views and who had harbored hopes of his son studying the Bible and expanding his Christian faith. Charles did eventually follow his father's advice after dropping out of college where he had spent the better part of a year. He found God at the age of nineteen and, in the same year, he joined a religious cult called the Oneida Community, which was run by the religious polygamist John Humphrey Noyes. Guiteau wrote to his brother-in-law in 1861 saying that, "The Oneida Community is the beginning of the kingdom of God on earth." years with the community until he abruptly decided to leave one day to pursue a career in journalism. After that point, he bounced back and forth between the Oneida Community and various odd jobs until he left the community for the last time in 1868. Guiteau wrote a letter saying goodbye to those he was leaving at Oneida and said, "It all means preparation for the great work of my life, which is to give Jesus Christ a daily paper." At that time, Noyes wrote to Guiteau's father that his son was "unquestionably not sane."6

As an adult Guiteau never smoked, drank, or gambled. His one constant was the Bible which he read as much as he possibly could. It was the only personal possession that went with him everywhere. Guiteau's continued religious involvement and delusional nature increased as he grew older. In 1873 he told his priest that he was suffering from "a vile and loathsome disease."7 Clearly, even he could see that something was indeed wrong with his mind. In 1876, he stayed briefly with his sister Frances and her husband. One day, while Frances was checking on his progress chopping wood in the yard, Guiteau raised an axe towards his sister after she chided his laziness. Frances called the family physician immediately, and he proclaimed her brother as being insane. ${ }^{8}$ Instead of being committed to an asylum at the time as he likely should have been, Guiteau escaped through the back door, taking only his Bible with him. A loner by all accounts, his sister described his childhood by saying, "I never knew him to do as other young men did in regard to 
games, or playing, or swimming, or anything at all like other young men. He was always by himself." 9 In the late 1870 s Guiteau held religious lectures and wrote a book called Truth that heavily plagiarized the Bible and the work of other theologians. ${ }^{10}$ At a lecture in 1877 in Chicago, Guiteau preached about "The Second Coming of Christ at the Destruction of Jerusalem" and charged an admission fee of twenty-five cents, but he allowed those who could not pay to attend without cost. ${ }^{11}$

Guiteau's interests took a shift towards politics around this time and his antics in that realm were just as far-fetched as his previous work. They displayed the signs of a man who was mentally unwell and in need of therapy and professional treatment. In 1880, he decided to support James Abram Garfield in his Presidential election bid against Winfield Hancock, and he performed several administrative tasks for the campaign. Once Garfield had been elected as President, Guiteau began lobbying for a position as an ambassador to Paris or Vienna. When his repeated written requests went unanswered, he approached Secretary of State James Blaine in May 1881 to discuss the matter and was told, "Never to speak to me again on the Paris consulship as long as you live." ${ }^{2}$ Regardless of the fact that he was not even remotely qualified to hold the position of foreign ambassador, Guiteau was crushed by this response. One of the motivating factors in his shooting of Garfield was this blatant rejection of Guiteau's political aspirations. ${ }^{13}$ It would be hard to imagine Guiteau carrying out the crime if he had somehow managed to gain the appointment. Guiteau was also upset with Garfield's selection of certain "Half-Breed" senators while overlooking other "Stalwart" candidates. ${ }^{14}$ In his interpretation, the violent action towards Garfield was seen as a necessity for restoring order to the Republican Party.

Guiteau's behaviour in the weeks leading up to the attack continued his pattern of mental unease. Two weeks prior to the shooting, Guiteau submitted an application for a pension as an applicant for a foreign mission with the government. He was examined by experts from the Pension Medical Board who pronounced him insane and rejected his application. ${ }^{15}$ During this time, Guiteau also made multiple visits to the jail that he would later be brought to after shooting Garfield. Jail officials denied him entry after he requested a visit to the inside of the facility and he was seen observing the scaffolding from which murderers were hanged. ${ }^{16}$ Guiteau stalked the President for days, waiting for the most opportune moment to carry out his plan. He came close to carrying out the shooting on two separate occasions, but time he could not complete the task. The first time, he felt sorry for Garfield's wife, who was with him, and the second time, was without a clear shot. ${ }^{17}$

On July 2, 1881 at 9:20am, President Garfield entered the Pennsylvania railroad station in Washington to catch a train to Williamstown for a class reunion. He was shot twice from behind by Charles Guiteau. The first shot grazed the President's arm, while the second entered through his back and lodged near his spine. Garfield clutched his back, and cried out, "Oh my God!" and fell to the ground unconscious. Guiteau remained still, waiting to be apprehended by a nearby police officer. ${ }^{18}$ Garfield did not succumb to his injuries for twelve weeks, although his outlook for survival was bleak throughout this entire period.

The President had known of the risks involved in his position and in fact had predicted that such an attack was a distinct possibility when he once said,

"I have always supposed that a man who occupies so exalted and powerful position, as does the President of the United States, must exert a fatal fascination over a man of morbid mind, who seeks his life for revenge or any other motive.",19

The man of the morbid mind was Charles Guiteau. Before he died, Garfield's advisors were queried by the press as to whether or not the President had asked about Guiteau during his time in the hospital. They replied that the President had only ever asked for Guiteau's name and what had happened to him. Garfield remarked after hearing about Guiteau, "He must have been crazy. Not but an insane person could have done such a thing. What could he have wanted to shoot me for?"20

Shortly after his arrest Guiteau was found to have been carrying a newspaper article concerning some controversial partisan senate appointments made by Garfield. The article was highlighted in certain areas and contained notes scribbled by Guiteau that indicated he had been pondering its contents for some time. ${ }^{21} \mathrm{He}$ also carried with him two letters he had written that attempted to explain his motives for the attack. His comments leave little doubt that he exhibited insane ideas and conceptions of his role in the attack:

I presume the President was a Christian, and that he will be happier in Paradise than here. It will be no worse for Mrs. Garfield, dear soul, to part with her husband this way than by natural death. He is liable to go at any time, anyway. I had no ill-will towards the President. His death was a political necessity. ${ }^{22}$

Guiteau also made a plethora of comments that eventually reached the media and fueled intense scrutiny over his motives for shooting the President. In these comments the grand illusions that possessed him at the time become clear:

I wish to say emphatically on the threshold of my examination, that my getting office or not getting office had nothing to do with my attempt to remove the President. That was a political necessity under Divine pressure....Inspiration, as I understand it is where a man's mind is taken possession of by a superior power, and where he acts outside of his own natural - outside of himself. I stated there that 
the Lord inspired me to attempt to remove the President in preference to someone else, because I had the brains and the nerve to do the work, and because the Lord always employs the best material to do his work. ${ }^{23}$

His comments expose a belief that his work was politically motivated and, at the same time, that he saw himself as an instrument of God. The clarity and confidence in his words are apparent and he maintained this attitude throughout the period leading up to and during his trial. His comments about his motivation for the attack never waivered nor changed, implying that he truly believed that what he was saying was true.

The Guiteau trial was nothing short of a media circus that captured the minds of Americans everywhere. ${ }^{24}$ Twentyfour medical specialists were called to testify at the trial, and eight of them (four for the defense and four for the prosecution) were respected enough to be included in the Dictionary of American Biography due to their accomplishments. ${ }^{25}$ The experts all varied in their assessment of Guiteau's sanity, which proved that at the time nobody quite knew exactly what it meant by the legal term "insane." ${ }^{26}$ After these experts finished testifying, Judge Cox remarked to the jury, "I hold that a medical expert cannot say whether a man may be responsible or irresponsible in the law." ${ }^{27}$ The judge's comments no doubt had an influence on the jury in this matter.

Guiteau began the proceedings each day by going off on wild tangents, regularly interrupting lawyers and witnesses, and behaving in the manner of someone who was quite unbalanced. He continued to display his odd religious beliefs; he questioned prospective jurors on their views towards the Bible and often implied that he spoke for God. His own defense team was hardly prepared to handle a case of this magnitude. Leigh Robinson quit as lead defense counsel after only a week because of apparent conflicts with Guiteau on how he should proceed with his defense strategy.

In court on November 17, 1881, Guiteau rose at the start of the day's proceedings and stated, "May it please the court, I object to Mr. Robinson appearing in this case." ${ }^{28}$ Robinson had wanted to argue that the medical malpractice of doctors working on the President were responsible for his death and not the bullets that had come from Guiteau's gun. There was much truth to this claim and medical experts in the twentieth century tended to agree with this possibility. ${ }^{29}$ Infection had set in from the unwashed fingers of surgeons examining the President. The merits of hand washing and sterilizing medical instruments had not yet been realized, and theories of antisepsis were not widely accepted. ${ }^{30}$ Regardless of the strengths of this tactic, it was abandoned when Robinson quit the defense team. The fact that Guiteau disagreed with the only legitimate legal mind at his disposal displays a continuation of his insane behaviour. Guiteau even interrupted Robinson at one point during the first week of trial to say, "I would not trust Robinson with a ten dollar suit. He hasn't got brains enough." 31 Instead Guiteau represented himself with the assistance of his brother-in-law, George Scoville, whose only previous legal expertise was in examining land titles. ${ }^{32}$ From that moment on, the defense was anchored by the insanity plea. The jury was not swayed by any of the in-court antics of the defendant or by his plea of insanity. They convicted him in just over an hour of deliberations.

Outside of the courtroom there was a variety of opinions on what motivated Charles Guiteau to assassinate the President. While many people agreed that Guiteau was not mentally stable, most believed that his antics were simply an act. The public at the time was often enraged with not-guilty verdicts in cases of supposed insanity. ${ }^{33}$ Guiteau's attempt at using this method of defense failed and drew the wrath of the public. $^{34}$ Insanity was not well-understood at the time and the average layperson likely knew less about this form of illness than any other important form of serious disease. ${ }^{35}$ It was the general belief at the time that anyone could spot an insane person when they saw them, ${ }^{36}$ which is hard to believe in a defense, if one does not completely understand the facts. A lack of information about mental illness contributed to the public opinion that surrounded the Guiteau defense. Insane or not, Americans stood united in the fact that they wanted to see justice come down on the man who had murdered their leader.

Scholars over the past hundred and twenty-seven years have also taken a range of opinions towards Guiteau and his legal culpability. Some of the early writings clearly display a lack of compassion for whatever condition may have inflicted Guiteau. In fact, many refer to Guiteau as merely a "disappointed office-seeker" and make no mention of his mental illness at all. ${ }^{37}$ This was the typical manner in which Guiteau was described for some sixty years after the murder. ${ }^{38}$ Writing in 1881 , after the assassination but before the criminal trial, William Ralston Barch noted,

"All this time possibly the reader has asked what of the assassin? I have purposely reserved any notice of this miscreant as long as convenient, for I do not dream him deserving of any more notice than is rendered absolutely necessary to comprehend the full story." 39

Dr. Charles Follen Folsom, in a privately printed book on the subject of criminal responsibility, wrote in 1908,

"Even if he were shamming, as I think he was to a certain extent, that is as much a characteristic of the insane as of the sane. It seems to me to belong to that class of insane criminals who do least harm to society after their crime by being secluded for life in a criminal lunatic asylum without trial, if that is practicable in our country." 40 
In 1925, Theodore Clarke Smith described Guiteau as, "a man not insane in the ordinary sense of the word, but certainly abnormal in his egotism, restless self-assertion and desire for publicity. Intellectually and morally he was eccentric to a degree that left him just above technical irrationality" $" 41$ In 1950, Stewart A. Fish wrote that, "Guiteau was undoubtedly insane, but the exact nature of his psychosis was never determined." 42 More recently, Justus D. Doenecke wrote in 1981 that Guiteau was, "a victim of mental illness" and that he manifested a, "common garden variety of paranoid schizophrenia." immediately following the trial, most assessments of Guiteau did not contain any medical diagnoses but rather only the personal opinions of the individual writers. ${ }^{44}$ This seems to be the prevalent view of scholars and historians in the past fifty years as the use of the insanity defense became more understood in North American society. The quotes above demonstrate an evolving insight into the use of the insanity defense, and the earliest viewpoints are representative of how American society felt at the time about Guiteau's supposed insanity. It is hard to fault jurors and their contemporaries for their feelings about the subject in the nineteenth century; there simply was not enough evidence or examples of similar cases at the time to expect otherwise.

Yet, there were a few other high-profile instances of the insanity defense that had occurred up to that point both in North America and elsewhere. In 1628, the Duke of Buckingham was assassinated by John Felton who acted in the supposed "good and safety" of the Kingdom of England. ${ }^{45}$ Felton, like Guiteau, made no attempt to escape after the attack. The insanity defense was used in this case as well, but it ended with the same result as Guiteau. Felton was hanged on August 23, 1628. In 1859, United States Congressman Daniel Edgar Sickles shot and killed Philip Barton Key, the son of the author of "The Star Spangled Banner" and he used a defense based upon an insanity plea.

In his case, Sickles was a high-profile accused and was able to pay a sizeable sum of money to hire prominent lawyers who managed to get him acquitted. Guiteau did not have access to such funds, nor was he interested in keeping any lawyers of repute on his team. In 1836, Richard Lawrence attempted to shoot then-President Andrew Jackson. Both of the pistols he had on him misfired that day, and he was acquitted on the grounds of insanity and sent to an asylum. Lawrence claimed he was the deposed King of England, Richard III, who had been dead since 1485 and that Jackson was one of his clerks. A common theme among these judgments was that if the intended victim survived the attack, in most of these cases they were treated as if they were insane and committed to a mental institution rather than being treated as criminals. ${ }^{46}$ Once a life was taken however, juries were less likely to believe this defense and, unless the accused could afford a good legal team, they were likely put to death. ${ }^{47}$
After reviewing the facts surrounding Charles Guiteau and his involvement in the assassination of American President James Garfield, it is evident that he was insane. Whether or not that absolves someone of a crime they commit is not the purpose of this research. Certainly if Guiteau had been found to have been insane by the jury, he would not have been put to death and would have instead ended up in a mental asylum. If his case had occurred fifty years later, he would have stood a better chance at being seen for what he truly was. Guiteau's insanity had been brewing since his days as a youth. Family occurrences of mental illness may have been partially responsible. His time surrounded by religious fanatics at the Oneida Community shaped his own unique and fanatical views of religion and the role it played in his assassination of Garfield. His actions leading up to the shooting and after his arrest also serve to demonstrate his continued struggle with insanity. At numerous times prior to the shooting he was deemed by different people he came across, professional and otherwise, as being insane.

By refusing the help of his one criminal attorney and acting in the outrageous manner he did throughout the trial, he also caused great harm to his chances of developing an understanding by the jury who saw him as a good actor rather than one who was truly insane. ${ }^{48}$ Judging from the amount of early scholarly opinion on the trial, it also can be seen how American society in the nineteenth century and in the immediate years following was not prepared to accept the notion that Guiteau was truly insane.

Historians and scholars in more recent years have all but ruled out Guiteau's disgruntled political aspirations as the sole cause of his actions. His overwhelming insanity is now widely regarded as the true motivation for the attack on Garfield. As he was about to be executed on June 30, 1882, Charles Guiteau cried out, "I saved my party and my land, Glory Hallelujah!"49 Even in his last moments, Guiteau displayed that he was indeed insane.

\section{ENDNOTES}

${ }^{1}$ Justus D. Doenecke, The Presidencies of James A. Garfield and Chester A. Arthur (The Regents Press of Kansas, 1981), 95.

2 Stewart A. Fish, "The Death of President Garfield" Bulletin of the History of Medicine 24 (1950): 391.

3 Stewart Mitchell, "The Man Who Murdered Garfield," Historical Society 67 (Oct. 1941-May 1944): 457.

${ }^{4}$ Ibid., 459.

5 Ibid., 459.

${ }^{6}$ Ibid., 457.

${ }^{7}$ Ibid., 461.

${ }^{8}$ Ibid., 463.

${ }^{9}$ Ibid., 463.

10 “Guiteau's Inspiration,” New York Times (Dec. 1, 1881). 
${ }^{11}$ Mitchell, "The Man Who Murdered Garfield," 463.

12 Ibid., 466.

${ }^{13}$ E. Hilton Jackson, "The Trial of Guiteau," The Virginia Law Register 9, no. 12 (Apr., 1904): 1023.

${ }^{14}$ Ibid., 1024.

${ }^{15}$ Ibid., 1028.

${ }^{16}$ William Ralston Balch, The Life of James Abram Garfield: Late President of the United States (Philadelphia: A. Gorton and Co., 1881): 667.

${ }^{17}$ Robert Granville Caldwell, James A. Garfield : Party Chieftain (Dodd, Mead and Company Inc., 1931): 350.

${ }^{18}$ Doenecke, The Presidencies of James A. Garfield, 53.

${ }^{19}$ Balch, The Life of James Abram Garfield, 673.

${ }^{20}$ Theodore Clarke Smith, The Life and Letters of James Abram Garfield - Volume Two 1877-1882 (Yale University Press, 1925), 1195.

${ }^{21}$ Ibid., 1185.

${ }^{22}$ Balch, The Life of James Abram Garfield, 673.

23 "Guiteau's Inspiration.".

${ }^{24}$ Kessel Schwartz, "Jose Marti, "The New York Herald" and President Garfield's Assassin," Hispania 56 (Apr., 1973): 137.

${ }^{25}$ Mitchell, "The Man Who Murdered Garfield,” 469.

${ }^{26}$ Caldwell, James A. Garfield, 351.

${ }^{27}$ Mitchell, "The Man Who Murdered Garfield," 470.

28 "Proving Guiteau's Crime," New York Times (Nov., 18, 1881).

${ }^{29}$ Fish, "The Death of President Garfield," 378.

${ }^{30}$ Ibid., 378.

${ }^{31}$ Schwartz, "Jose Marti," 137.

32 Jackson, "The Trial of Guiteau," 1027.

${ }^{33}$ Bruce Bower, "Not Popular by Reason of Insanity,"

Science News 126, no. 14 (Oct. 6, 1984): 218.

${ }^{34}$ Ibid., 218.

${ }^{35}$ Edward Huntington Williams and Ernest Bryant Hoag, "Misconceptions of Insanity in Jury Trials," California Law Review 11, no. 1 (Nov., 1922): 1-11.

${ }^{36}$ Ibid., 2.

${ }^{37}$ Rev. Samuel Fallows, Life of William McKinley our Martyred President (Chicago: Regan Printing House, 1901), 341.

${ }^{38}$ Mitchell, "The Man Who Murdered Garfield," 452.

${ }^{39}$ Balch, The Life of James Abram Garfield, 664.

${ }^{40}$ L. Vernon Briggs, "Medico-Legal Insanity and the Hypothetical

${ }^{41}$ Smith, The Life and Letters, 1184.

${ }^{42}$ Fish, "The Death of President Garfield," 391.

${ }^{43}$ Doenecke, The Presidencies of James A. Garfield, 95.
${ }^{44}$ Ibid., 95.

${ }^{45}$ Mitchell, "The Man Who Murdered Garfield," 453.

${ }^{46}$ Lawrence Zelic Freedman, "The Politics of Insanity: Law, Crime and Human Responsibility," Political Psychology 4, no. 1 (Mar., 1983): 171-178.

${ }^{47}$ Jackson, "The Trial of Guiteau," 1029.

${ }^{48}$ Mitchell, "The Man Who Murdered Garfield," 470.

${ }^{49}$ Doenecke, The Presidencies of James A. Garfield, 96.

\section{REFERENCES}

Balch, William Ralston. The Life of James Abram Garfield: Late President of the United States.Philadelphia: A. Gorton and Co., 1881.

Bower, Bruce. "Not Popular by Reason of Insanity." Science News 126, no. 14 (Oct. 6, 1984): 218-219.

Briggs, L. Vernon. "Medico-Legal Insanity and the Hypothetical Question." Journal of the American Institute of Criminal Law and Criminology 14, no. 1 (May, 1923): 62-74.

Caldwell, Robert Granville. A. Garfield: Party Chieftain. Dodd, Mead and Company Inc., 1931.

Doenecke, Justus D. The Presidencies of James A. Garfield and Chester A. Arthur. The Regents Press of Kansas, 1981.

Fallows, Rev. Samuel. Life of William McKinley our Martyred President. Chicago: Regan Printing House, 1901.

Fish, Stewart A. "The Death of President Garfield." Bulletin of History of Medicine 24, (1950):378-392.

Freedman, Lawrence Zelic. "The Politics of Insanity: Law, Crime and Human Responsibility."Political Psychology 4, no.1 (Mar., 1983): 171-178.

Jackson, E. Hilton. "The Trial of Guiteau." The Virginia Law Register 9, no. 12 (Apr., 1904):1023-1035.

Mitchell, Stewart. "The Man Who Murdered Garfield."

Historical Society 67,(Oct., 1941-May, 1944): 452-489.

Schwartz, Kessel. "Jose Marti, "The New York Herald" and President Garfield's Assassination."Hispania 56, (Apr., 1973): 335-342.

Smith, Theodore Clarke. The Life and Letters of James Abram Garfield: Volume Two. York University Press, 1925.

Williams, Edward Huntington and Ernest Bryant Hoag. "Misconceptions of Insanity in Jury Trials." California Law Review 11, no.1 (Nov., 1922): 1-11. 